\title{
Effect of Dietary Energy Sources on the Utilization of Protein by Colossoma macropomum Fingerlings
}

\author{
Martha Hernández, Toshio Takeuchi, ${ }^{\dagger}$ and Takeshi Watanabe \\ Department of Aquatic Biosciences, Tokyo University of Fisheries, Konan, Minato, Tokyo 108, Japan \\ (Received October 12, 1994)
}

\begin{abstract}
The effects of dietary energy sources on protein utilization by Colossoma macropomum fingerlings were studied. The fish were fed to satiation seven experimental isocaloric semi-purified casein diets with increasing dietary protein levels (from 0 to $48 \%$ ). The energy content was adjusted with carbohydrates in four diets $(11,20,31$ and $48 \%$ protein) and with lipids in two diets ( 28 and $36 \%$ protein).

Daily feed consumption decreased and percent gain and feed efficiency increased with an increase in dietary protein. Dietary protein requirement was found to be more than $31 \%$ when carbohydrates were used as the energy source. Protein efficiency ratio and net protein utilization were inversely proportional to the dietary protein content and no negative effect of carbohydrates on protein utilization was observed. In terms of feed efficiency and protein efficiency ratio, the lipid and carbohydrate groups responded in a similar way to the dietary protein levels. Carbohydrates seemed to be effective as a dietary energy source for this species. The whole body lipid content was inversely proportional to the dietary protein level and was higher in fish fed the lipid diets than in those fed the carbohydrate diets.
\end{abstract}

Key words: Colossoma, diet, energy sources, protein

The potential for aquaculture of the South American freshwater fish Colossoma macropomum has been widely recognized and the fish are being cultured in different tropical countries." The technology for induced breeding has already been developed and applied to practical fly production. However, little is known about the nutritional requirements of the species. ${ }^{2,3)}$ Under natural conditions, juveniles are omnivorous and eat mainly fruits, seeds, and zooplankton. ${ }^{4)}$ Adults are basically flugivorous and eat fruits ad seeds, ${ }^{5}$ which are rich in both lipids and carbohydrates. Their natural feeding habits indicate that they are probably capable of utilizing carbohydrates as well as lipids as energy sources.

Several studies on the protein requirement of $C$. macropomum have produced different results. Macedo et al., ${ }^{\text {) }}$ from experiments conducted in rearing ponds, mentioned that 22 and $18 \%$ dietary protein levels were adequate for early fingerling ( 5 to $30 \mathrm{~g}$ ) and juvenile stages, respectively. Eckmann, ${ }^{7)}$ working with fingerlings in wooden box aquaria, found that growth rate increased when the dietary protein level increased from 25 to $37 \%$. Merola and Cantelmo $\left.{ }^{8}\right)$ using floating cages in a lake, tested three diets with 30,35 and $40 \%$ crude protein levels and obtained no significant difference in mean final body weight. Luna, ${ }^{9}$ in an experiment carried out in concrete tanks, obtained better growth with $31 \%$ than with $17 \%$ dietary protein level. Valencia, ${ }^{10)}$ using fertilized rearing ponds, tried diets with 23,25 and $27 \%$ crude protein levels and recorded the highest growth with the highest protein level.

Within this background, the present study compared the efficiency of carbohydrates and lipids as energy sources based on their effect on protein utilization, and estimated the dietary protein requirement of C. macropomum when carbohydrates are used as the energy source. Due to scanty information on this species, comparisons are made with common carp Cyprinus carpio as a model fish.

\section{Materials and Methods}

Fingerlings of $C$. macropomum weighing $0.5 \mathrm{~g}$ on average were supplied to the Laboratory of Fish Nutrition, Tokyo University of Fisheries, by a Japanese company, Far East Enterprise. The fish were obtained from Acuacultura las Brisas, a fry production farm in Colombia, and were exported by Savannah Tropical Fish company. During the two month conditioning period they were fed with a commercial common carp diet.

\section{Diets}

Seven isocaloric diets with varying levels of protein were prepared (Table 1). The formulations were very similar to those used in a previous study with common carp, ${ }^{11)}$ in order to compare the results of both species. Diets contained increasing levels of protein from $0 \%$ (NP) to $48 \%$ (C48). Vitamin-free casein supplied by Oriental Yeast Co., Ltd., Tokyo, was used as the protein source, with a purity of approximately $90 \%$ crude protein. The diets were formulated to be isocaloric at an estimated digestible energy of around $385 \mathrm{kcal} / 100 \mathrm{~g}$, based on the digestible energy values of $4.5 \mathrm{kcal} / \mathrm{g}$ for protein, $8.5 \mathrm{kcal} / \mathrm{g}$ for lipid and 4 $\mathrm{kcal} / \mathrm{g}$ for carbohydrates, from previous experiments with common carp and Oreochromis niloticus. ${ }^{1,12)}$ All diets contained $15 \%$ extruded potato starch (Asahi Kagaku Kogyo Co. Ltd.) as a binder, $15 \%$ dextrin and $6 \%$ lipid. The lipid source was a mixture of soybean oil and pollock liver oil in the same proportion, assuming that this would satisfy the

\footnotetext{
† To whom correspondence should be addressed.
} 
Table 1. Composition of the experimental diets (\%)

\begin{tabular}{lrrrrrrr}
\hline & NP & C11 & C20 & L28 & C31 & L36 & C48 \\
\hline Casein (vitamin-free) & 0 & 11 & 22 & 28 & 33 & 39 & 50 \\
Extruded potato starch & 15 & 15 & 15 & 15 & 15 & 15 & 15 \\
Dextrin & 60 & 60 & 48 & 15 & 37 & 15 & 20 \\
Lipid*1 & 11 & 6 & 6 & 19 & 6 & 14 & 6 \\
Mineral mix. ${ }^{14)}$ & 5 & 5 & 5 & 5 & 5 & 5 & 5 \\
Vitamin mix. & 1 & 1 & 1 & 1 & 1 & 1 & 1 \\
Choline chloride & 0.4 & 0.4 & 0.4 & 0.4 & 0.4 & 0.4 & 0.4 \\
Vitamin E (50\% pure) & 0.1 & 0.1 & 0.1 & 0.1 & 0.1 & 0.1 & 0.1 \\
Cellulose & 7.5 & 1.5 & 2.5 & 16.5 & 2.5 & 10.5 & 2.5 \\
Chemical Analyses & & & & & & & \\
Moisture & & & & & & & \\
Crude protein & 5.8 & 6.8 & 8.7 & 5.8 & 8.0 & 9.1 & 5.7 \\
Crude lipid & 0.26 & 10.7 & 20.4 & 28.4 & 31.0 & 36.3 & 47.7 \\
Crude starch & 9.9 & 5.4 & 5.4 & 16.1 & 5.4 & 12.1 & 5.5 \\
Crude ash & 73.6 & 73.0 & 60.9 & 29.4 & 51.1 & 29.7 & 34.0 \\
\hline Estimated DE & 3.7 & 3.9 & 3.8 & 4.0 & 4.1 & 4.0 & 4.4 \\
\hline
\end{tabular}

*1 Soybean oil: pollock liver oil, 1:1.

*2 $(\mathrm{kcal} / 100 \mathrm{~g}$ ). The digestible energy (DE) was calculated as follows: 4.5 $\mathrm{kcal} / \mathrm{g}$ protein, $8.5 \mathrm{kcal} / \mathrm{g}$ lipid and $4 \mathrm{kcal} / \mathrm{g}$ carbohydrate.

essential fatty acid requirements. ${ }^{13)}$ The mineral and vitamin mixtures were the same as those described in Ogino et $a l{ }^{14)}$ and Ogino and Yang, ${ }^{15)}$ respectively. After incorporation of the basic ingredients, the diets were adjusted to attain the desired digestible energy level. The "carbohydrate diets" named C11, C20, C31 and C48, were adjusted with dextrin and the "lipid diets" named L28 and L36, with the lipid mixture. Finally cellulose was used as a non-nutrient filler. A non-protein diet (NP) was used for the determination of net protein utilization (NPU).

\section{Experimental Procedures}

The fish were prefed on diet C31 for 15 days, in order to adapt to the subsequent casein-based experimental diets. Feeding experiments were conducted with fingerlings of $C$. macropomum having an initial body weight of $8.4 \pm 0.9 \mathrm{~g}$. The fish were distributed randomly in $70 \mathrm{l}$ aquaria, at a density of $20 \mathrm{fish} /$ tank. For each treatment, duplicate aquariums with aeration and running water at a rate of $200-300 \mathrm{ml} / \mathrm{min}$ were used. The water temperature was maintained at $25.5 \pm 0.5^{\circ} \mathrm{C}$. The fish were fed to satiation three times daily $(09: 30,13: 30$ and $17: 30 \mathrm{~h})$ for 18 days. The experimental diets were fed in a dry pellet form. At the beginning and end of the feeding trial the fish were anesthetized with 2-phenoxyethanol (300 ppm) and they were weighed individually. Initial and final samples of 12 fish from each tank were taken for whole body composition analyses.

\section{Analytical Methods}

Experimental diets and whole body were analyzed for proximate composition, including crude starch for diets. Three determinations were made for whole body protein and two for the other chemical analyses. Moisture content was determined by desiccation at $105^{\circ} \mathrm{C}$ until constant weight and ash content by incineration in a muffle furnace at $550^{\circ} \mathrm{C}$. Crude protein $(\mathrm{N} \times 6.25)$ was determined using a Kjel-Auto (Mitamura Riken Kogyo Inc. VS-KT.P.Japan) after acid digestion. For lipid and starch analyses, the Folch and Somogyi-Nelson methods were used respectively.

NPU was measured by the carcass analysis technique of Miller and Bender ${ }^{16)}$ and calculated using the following formula:

$\mathrm{NPU}(\%)=100 \times$

Carcass $-\mathrm{N}$ increased $(\mathrm{g})+\{($ Initial + Final $) / 2$ (body wt. $\mathrm{g}) \times \mathrm{C} \times 10^{-5} \times$ days $\}$ Protein $-\mathrm{N}$ consumed $(\mathrm{g})$

where $C$ is the daily body nitrogen decrease with NP diet (mg/100 g body wt./day).

Protein retention (\%) was calculated as follows:

Protein retention $=100 \times\{($ Final protein content - Initial protein content) /Protein intake\}

\section{Statistical Analyses}

The means of the final body weight of the duplicates for each treatment were compared using the single-factor analysis of variance at a significance level of $p<0.05$, but no significant difference was found for any of the seven sets of duplicates. Therefore, they were combined and analyzed as a single unit.

After the previous test, the seven experimental groups were analyzed using Tukey's multiple comparisons test to compare the differences between the means of the final body weight at a significance level of $p<0.05$.

\section{Results}

\section{Growth Performance and Protein Utilization}

The results of the feeding trial are presented in Table 2. For the carbohydrate diets $\mathrm{C} 11, \mathrm{C} 20, \mathrm{C} 31$ and $\mathrm{C} 48$, the daily feed consumption (DFC) decreased with increasing dietary protein levels. For the lipid diets L28 and L36, the DFC was very similar, and was not related to the protein level. As shown in Figs. 1 and 2, percent gain and feed efficiency (FE) distinctly increased with increased dietary protein level. Growth performance was the best with the C48 diet. Within the groups of the carbohydrate diets the means for the final body weight were all significantly different. The values for percent gain and FE with diets L28 and L36 were close to those with the carbohydrate diets, except for a lower percent gain obtained with L28 (Figs. 1 and 2). On comparing C20 and L 28 there was no significant difference in their final body weights.

From the body protein content of fish fed the NP diet, the daily body nitrogen decrease $(C)$ was calculated. Because the diet contained some protein $(0.26 \%)$, this amount was included in $C$. The value obtained for $C$ was $11.7 \mathrm{mg} \mathrm{N} / 100 \mathrm{~g}$ body wt./ day.

The protein utilization efficiency was evaluated in terms of protein efficiency ratio (PER) and NPU, and their relationship with the dietary protein level is shown in Table 2 and Figs. 3 and 4. The PER showed an increase with a decrease of protein levels and the carbohydrate and lipid diets followed the same trend. The same relationship was also observed for the NPU in the carbohydrate diet group, although not evident in the lipid group. Protein 


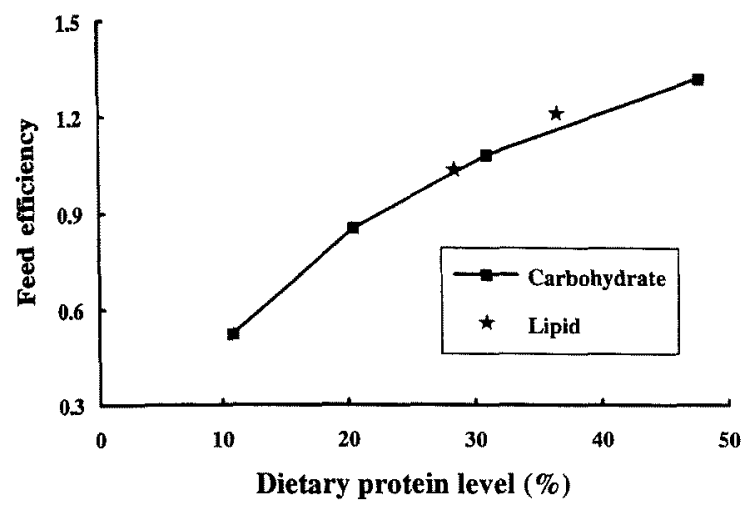

Fig. 1. Relationship between the dietary protein level and the percent gain of $C$. macropomum fed diets with high carbohydrate and high lipid contents.

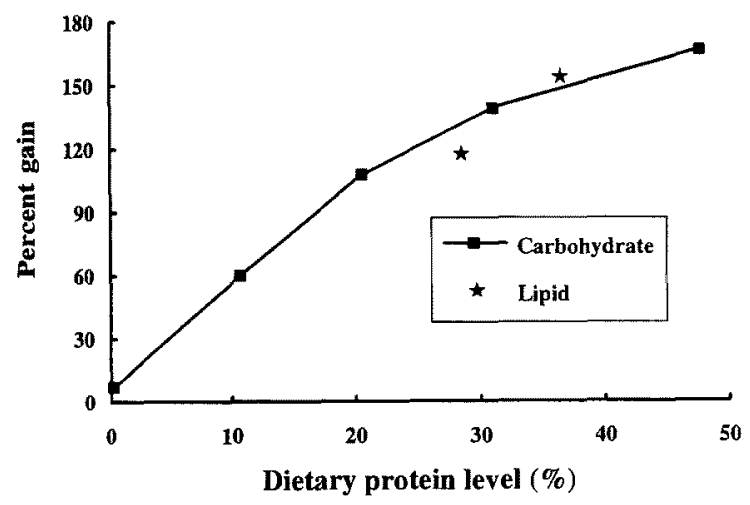

Fig. 2. Relationship between the dietary protein level and the feed efficiency of $C$. macropomum fed diets with high carbohydrate and high lipid content.

retention also decreased with increased dietary protein but the values for $\mathrm{C} 11$ and L28 were low considering the general tendency.

\section{Body Composition}

The proximate composition of the whole body is presented in Table 3. The crude protein content was lower in fish fed diets C11 and L28 and showed a slight increase with increasing dietary protein level. The crude lipid content decreased with an increase in the dietary protein content (decrease in non-protein energy) and was higher in fish fed the lipid diets than in those fed the carbohydrate diets (Fig. 5).

\section{Discussion}

A decrease in feed consumption with an increase in dietary protein level as noted in the present study has also been reported for pacu Piaractus mesopotamicus, ${ }^{3)}$ a species closely related to $C$. macropomum. The relatively low DFC obtained with diet L28 might be due to its high cellulose content. Wang et al. ${ }^{12)}$ reported that the feed consumption decreased with an increase of dietary cellulose levels in Oreochromis niloticus.
Table 2. Growth performance and protein utilization of C. macroponium for the 18-days feeding trial

\begin{tabular}{|c|c|c|c|c|c|c|c|}
\hline & NP & $\mathrm{Cl1}$ & $\mathrm{C} 20$ & L28 & $\mathrm{C} 31$ & L36 & $\mathrm{C} 48$ \\
\hline \multicolumn{8}{|c|}{ Average body weight $(\mathrm{g})^{*_{1}}$} \\
\hline \multirow[t]{2}{*}{ Initial } & 8.4 & 8.3 & 8.4 & 8.3 & 8.4 & 8.4 & 8.4 \\
\hline & \pm 0.9 & \pm 0.9 & \pm 1.0 & \pm 1.1 & \pm 0.9 & \pm 0.9 & \pm 1.0 \\
\hline \multirow[t]{2}{*}{ Final } & $8.9^{\mathrm{a}}$ & $13.4^{b}$ & $17.3^{\mathrm{c}}$ & $18.1^{\mathrm{c}}$ & $20.0^{d}$ & $21.2^{\mathrm{de}}$ & $22.4^{\mathrm{e}}$ \\
\hline & \pm 0.9 & \pm 1.6 & \pm 2.4 & \pm 2.9 & \pm 2.9 & \pm 2.5 & \pm 4.4 \\
\hline Percent gain & 7 & 60 & 107 & 117 & 139 & 154 & 167 \\
\hline $\mathrm{FE}^{* 2}$ & 0.13 & 0.52 & 0.85 & 1.04 & 1.08 & 1.21 & 1.32 \\
\hline $\mathrm{PER}^{* 3}$ & - & 4.82 & 4.17 & 3.64 & 3.48 & 3.33 & 2.77 \\
\hline $\mathrm{NPU}^{*}$ & - & 66.3 & 63.2 & 52.7 & 55.0 & 52.2 & 45.3 \\
\hline Protein retention & - & 52.7 & 55.3 & 46.3 & 49.4 & 47.1 & 41.3 \\
\hline DFC $^{* 5}$ & 2.91 & 4.98 & 4.56 & 3.97 & 4.22 & 3.99 & 3.82 \\
\hline
\end{tabular}

*1 Mean \pm Standard deviation $(\mathrm{n}=20$ in duplicate). Means without common superscript differ at $p<0.05$.

$*_{2} \quad$ Feed efficiency $=\mathrm{g}$ gain $/ \mathrm{g}$ feed.

*3 Protein efliciency ratio.

*4 Net protein utilization.

*s Daily feed consumption (\% body weight).

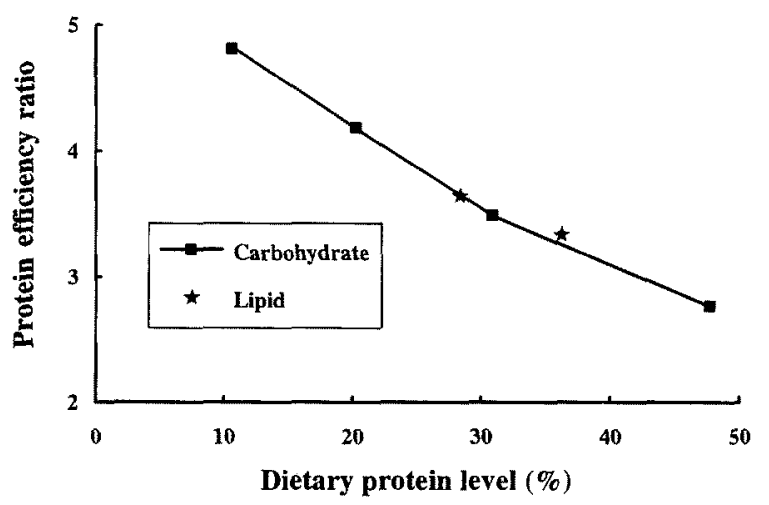

Fig. 3. Relationship between the dietary protein level and the protein efficiency ratio (PER) of C. macropomum fed diets with high carbohydrate and high lipid contents.

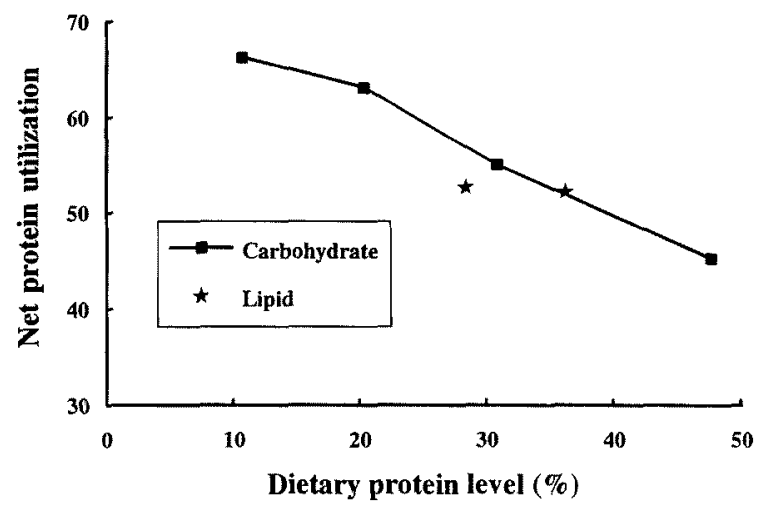

Fig. 4. Relationship between the dietary protein level and the net protein utilization (NPU) of C. macropomum fed diets with high carbohydrate and high lipid contents. 
Table 3. Whole body proximate composition of $C$. macropomum

\begin{tabular}{lrrrrrrrr}
\hline & Initial & NP & C11 & C20 & L28 & C31 & L36 & C48 \\
\hline Moisture & 78.7 & 72.9 & 71.3 & 72.3 & 69.8 & 72.9 & 72.2 & 73.1 \\
Crude protein & 14.9 & 12.8 & 13.4 & 14.0 & 13.7 & 14.5 & 14.4 & 14.9 \\
Crude lipid & 3.5 & 10.6 & 12.1 & 10.3 & 12.4 & 9.5 & 10.4 & 9.2 \\
Crude ash & 3.1 & 3.0 & 2.8 & 2.9 & 2.9 & 2.9 & 2.7 & 2.8 \\
\hline
\end{tabular}

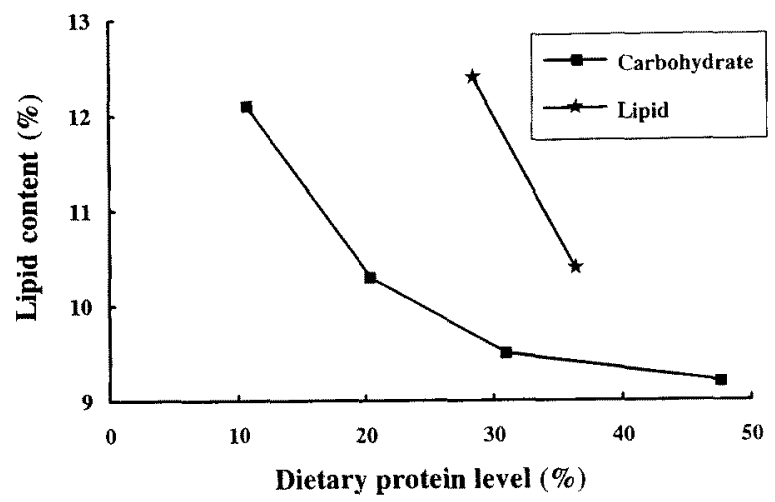

Fig. 5. Relationship between the dietary protein level and the whole body lipid content of $C$. macropomum fed diets with high carbohydrate and high lipid contents.

The present study showed that as was reported for common carp, ${ }^{11}$ both percent gain and feed efficiency increased with an increase in the dietary protein content, when carbohydrate was used as the energy source. A comparison between $C$. macropomum and common carp is made in Fig. 6, showing the relationship between the dietary protein level and the percent gain. A very similar pattern is observed in both species. C. macropomum fed diets $\mathrm{C} 31$ and $\mathrm{C} 48$ showed significant differences in their mean final body weight. Therefore, it appears that the protein requirement must be higher than $31 \%$ in the diet, when carbohydrates are used as the energy source. This corresponds with the results obtained by Eckmann,") where the growth rate with a $37 \%$ crude protein level was significantly higher than with a $32 \%$ level, using carbohydrate as the energy source.

The values of PER and NPU for C. macropomum were high at low protein levels and decreased as protein levels increased. Ogino et al. $^{11)}$ reported the same trends in rainbow trout when lipid was used as the energy source. However, when carbohydrates were used as the energy source at low protein levels, the values for PER and NPU were markedly reduced, demonstrating a negative effect of carbohydrates on protein utilization in rainbow trout. In the case of common carp PER and NPU were also high at low protein levels and decreased with the increase of dietary protein content. In C. macropomum as well as in common carp, carbohydrates did not exhibit any negative effect on protein utilization. Carbohydrates can thus be considered an effective dietary energy source for C. macropomum.

Percent gain, FE, PER and NPU for the two lipid diets resulted in very close values to those obtained with the car-

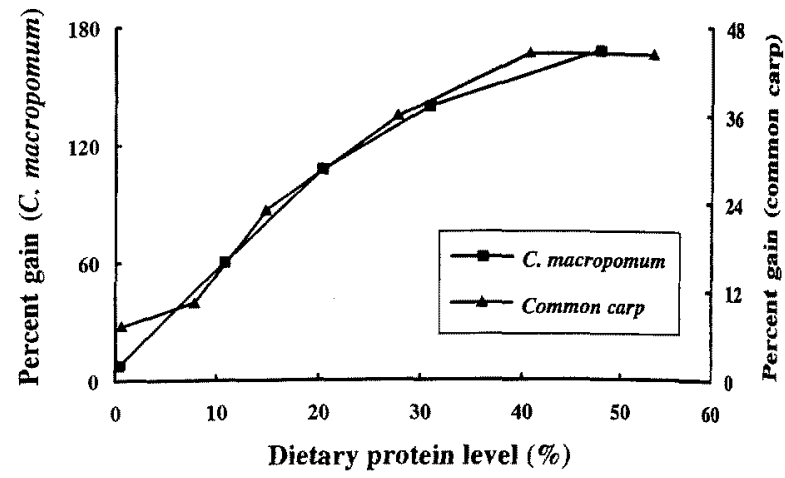

Fig. 6. Comparison of percent gain between C. macropomum and common carp fed diets with different protein levels and carbohydrate as the source of energy.

Values for common carp are from Ogino et al. (1976).

bohydrate diets, except for slightly lower values for percent gain and NPU for diet L28. This might be due to a negative effect of the high cellulose content and/or the high lipid content of the diet. Shimeno et al. ${ }^{17)}$ compared different carbohydrate to lipid ratios in diets for Oreochromis niloticus and recorded the lowest growth with the diet that contained only lipid and highest amount of cellulose.

From this preliminary trial, it seems that carbohydrates can be used effectively as a dietary energy source by $C$. macropomum. Further studies using isonitrogenous diets with different carbohydrate to lipid ratios would help to corroborate these observations. Such studies have already been done with common carp ${ }^{18)}$ and Tilapia zilli, ${ }^{19)}$ confirming that both carbohydrates and lipids can be used efficiently as dietary energy sources. In this study we used estimated values for digestibilities of the different nutrients. It would be useful to study the digestibility of each nutrient at different levels in order to make isocaloric diets and to determine the energy requirement and the optimum ratio of protein to energy for $C$. macropomum.

Considering whole body composition, the increase of lipid with a decrease in dietary protein level (increase in non-protein energy) was also observed by Ogino et al. ${ }^{11)}$ for rainbow trout with lipid diets and common carp with carbohydrate diets. The higher whole body lipid content obtained with lipid diets compared to carbohydrate diets

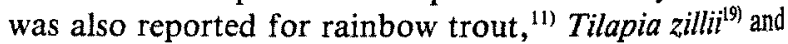
Oreochromis niloticus. ${ }^{17}$

The performance of $C$. macropomum linked to protein utilization, suggests that they resemble common carp in their ability to utilize carbohydrates. This aspect is of practical importance in the aquaculture of this South Amer: can fish, because carbohydrates are cheaper and more abundant sources of energy than lipids.

\section{References}

1) U. Saint-Paul: Potential for aquaculture of South American freshwater fishes: A review. Aquaculture, 54, 205-240 (1986).

2) D. J. Menton: Research considerations into the nutrition of Colos. soma and Piaractus in relation to culture conditions, in "Cultivo de Colossoma" (ed. by A. Hernández), Primera reunión grupo de trabajo técnico, Junio 20 al 24 de 1988 , Pirassununga, S. P. Brasil, Bogotá, Colombia, 1989, pp. 75-84. 
3) N. Castagnolli: Brazilian finfish, tambaqui, pacu, and matrinxã, in "Handbook of nutrient requirements of finfish" (ed. R. P. Wilson), CRC Press Inc., Boston, 1991, pp. 31-34.

4) E.M.S. Honda: Contribuição ao conhecimento da biologia de peixes do Amazonas. II. Alimentação de tambaqui, Colossoma bidens (Spix). Acta Amazonica, 4, 47-53 (1974).

5) M. Goulding and M. L. Carvalho: Life history and management of the tambaqui (Colossoma macropomum, Characidae): an important Amazonian food fish. Rev. Bras. Zool., 1, 107-133 (1982).

6) E. M. Macedo, D. J. Carneiro, and N. Castagnolli: Necessidades proteicas na nutrição do tambaqui Colossoma macropomum Cuvier, 1818 (Pisces, Characidae). An. Simp. Bras. Aqüicult. e 2. Enc. Nac. Ranicult., SUDEPE, Brasilia, p. 77 (1981)

7) R. Eckmann: Growth and body composition of juvenile Colossome macropomum Crivier 1818 (Characoidei) feeding on artificial diets. Aquaculture, 64, 293-303 (1987).

8) N. Merola and O. A. Cantelmo: Growth, feed conversion and mor tality of cage-reared tambaqui, Colossoma macropomum, fed various dietary feeding regimes and protein levels. Aquaculture, 66, 223-233 (1987).

9) T. Luna: The effect of dietary protein and energy content on the growth of Colossoma macropomum. (In Spanish with English abstract), in "Taller de trabajo sobre acuicultura en America Latina" (ed. by J. Verreth, M. Carrillo, S. Zanui and E. Huisman), International Foundation for Science (IFS), Lima, Peru, 1987, pp. 133-138.

10) O. Valencia: Estudio sobre el cultivo intensivo de la Cachama negra (Colossoma macropomum), alimentada con un concentrado isocalorico y 3 niveles diferentes de proteina, al $3 \%$ de su peso corporal, in "La cachama. Ensayos sobre nutrición y cultivo",
Inderena, Repelón, Colombia, 1989, pp. 25-31.

11) C. Ogino, J. Y. Chiou, and T. Takeuchi: Protein nutrition in fishVI Effects of dietary energy sources on the utilization of proteins by rainbow trout and carp. Nippon Suisan Gakkaishi, 42, 213-218 (1976).

12) K.-W. Wang, T. Takeuch, and T. Watanabe: Optimum protein and digestible energy levels in diets for Tilapia nilotica. (in Japanese with English abstract). Nippon Suisan Gakkaishi, 51, 141-146 (1985).

13) A. G. J. Tacon: The nutrition and feeding of farmed fish and shrimp-a training manual. 1. The essential nutrients. GCP/RLA/ 075/ITA FAO Field Document 2/E. Brasilia, Brasil, 1987, p. 92.

14) C. Ogino, L. Takeuchi, H. Takeda, and T. Watanabe: Availability of dietary phosphorous in carp and rainbow trout. (in Japanese with English abstract). Nippon Suisan Gakkaishi, 45, 1527-1532 (1979).

15) C. Ogino and G..Y. Yang: Requirement of rainbow trout for dietary zinc. Nippon Suisan Gakkaishi, 44, 1015-1018 (1978).

16) D. S. Miller and A. E. Bender: The determination of the net utilization of proteins by shortened method. Br. J. Nutr., 9, 382-388 (1955).

17) S. Shimeno, D.-C. Ming and M. Takeda: Metabolic response to dietary carbohydrate to lipid ratios in Oreochromis niloticus. Nippon Suisan Gakkaishi, 59, 827-833 (1993).

18) T. Takeuchi, T., Watanabe, and C. Ogino: Availability of carbohydrate and lipid as dietary energy sources for carp. (in Japanese with English abstract). Nippon Suisan Gakkaishi, 45, 977-982 (1979).

19) A. M. El-Sayed and D. L. Garling Jr.: Carbohydrate-to-lipid ratios in diets for Tilapia zillii fingerlings. Aquaculture, 73, 157-163 (1988). 